\title{
Sciendo
}

\section{Have the Baltic Countries Run Out of Labour Reserves? ${ }^{1}$}

\section{Olegs Krasnopjorovs}

\author{
Bank of Latvia \\ K. Valdemara 2A \\ Riga LV-1050, Latvia \\ Email: Olegs.Krasnopjorovs@bank.Iv
}

\begin{abstract}
The aim of the article is to study both the magnitude and structure of internal labour reserves in the Baltic countries as well as to discuss potential policy measures that might help to activate these reserves. Despite the record-high employment rates recently posted by Estonia, Latvia and Lithuania, considerable internal labour reserves can still be found in some population groups. Among upper-middle-aged men, low employment might reflect a low incidence of lifelong learning, inadequate digital skills and rapidly deteriorating health condition. Low employment of youth mirrors the low prevalence of apprenticeships. In Lithuania and Latvia, there is also a postponed entry of young women into the labour market. These internal labour reserves total more than 25,000 people in Estonia, 55,000 in Latvia and 85,000 in Lithuania, corresponding to $4-7 \%$ of the total employment. The recent outbreak of the Covid-19 pandemic may somewhat increase and change the structure of these labour reserves.
\end{abstract}

Keywords: employment, labour market, participation, unemployment

The chronic shortage of jobs and the double-digit unemployment rates in the Baltics were rooted in the painful transition of the 1990s and were common labour market features for almost the whole period since Latvia, Lithuania and Estonia restored independence in 1991. With just two exceptions. The first exception was the period of a short-lived economic

1 An earlier longer version of this article has been published as a discussion paper of Latvijas Banka (Krasnopjorovs, 2019a). 
overheating which culminated a couple of years after the EU accession in 2004. A unique combination of several factors-increasing availability of credit and the resulting real estate boom, inflows of EU funds and the emergence of emigration opportunities to high-wage EU countries-pressed unemployment well below the natural rate and provided the first incidence of labour shortage in the modern history of the Baltic countries. However, the shortage of jobs was quickly back on the agenda when the bursting of the domestic cyclical bubbles coincided with the global economic slowdown of 2009. Flexible labour markets of the Baltic countries allowed firms to quickly adjust wages and employment (Fadejeva \& Krasnopjorovs, 2015); as a result, the unemployment rate tripled to almost $20 \%$ in 2010 . At that time, it seemed that the mirage of near full employment would never return.

Nevertheless, a few years later, the Baltic countries managed to return to one-digit unemployment rates. Choosing internal adjustment as a strategy to exit the crisis and maintaining a fixed exchange rate vis-à-vis the euro (Åslund \& Dombrovskis, 2011) determined a fast output recovery, while flexible labour markets quickly secured a solid rise in labour demand. At the same time, the second massive emigration wave to wealthier EU countries, boosted by the crisis, dampened the labour supply. This time, severe economic overheating was avoided. However, the negotiating power of employees is gradually growing, and firms increasingly claim they lack labour to expand their businesses. As a result, wages have risen somewhat faster than labour productivity for several years in a row, which could imply decreasing cost competitiveness. To date, this second remission from the shortage of jobs disease has lasted for about six years, raising a question whether these improvements are permanent or merely a by-product of a strong cyclical upswing. In the latter case, the Covid-19 pandemic may likely to have a more prolonged impact on the labour market.

The article aims to study both the magnitude and structure of internal labour reserves in the Baltic countries as well as to discuss potential policy measures that might help to activate these reserves. In order to formulate medium-term policy directions (which should not be sensitive to a particular phase of the economic cycle), the scope of the paper is mainly limited to the labour supply side. Therefore, the objectives of the paper are to quantify the available labour reserves, identify the population groups requiring specific attention from policymakers (Section 1), outline the main policy directions to activate them (Section 2) as well as discuss the likely impact of the Covid-19 pandemic on the Baltic labour markets (Section 3). Finally, research limitations are discussed in Section 4. 


\section{Anatomy of internal labour reserves}

Labour is one of the production factors. However, part of available labour resources might not be utilised in production. Although different papers might use different definitions of labour reserves, this definition is commonly broader than just unemployed people. Usually, it consists of the jobless working-age population both within the labour force (i.e., jobseekers) and beyond the labour force (economically inactive population; see, for instance, Green \& Hasluck, 1998). In assessing the underemployment of different population groups, our methodology follows the spirit of Blanchflower \& Levin (2015). In this setup, labour reserves accumulate jobless labour pool across different population groups beyond a certain threshold (with the latter representing a performance of peer countries).

In order to sketch the magnitude of labour reserves, a broader overview of the structure of the working-age population is presented. The employed-topopulation ratios in Estonia, Lithuania and Latvia are somewhat above the EU average. This is mainly a result of a high participation rate. In all three Baltic countries, the participation rates currently are historically high and considerably exceed the EU average (Fig. 1). This result is partly driven by a temporary boost due to the changing population age structure, and this temporary effect is unlikely to persist. During the next few years, the narrow youth cohorts of today will enter the prime age group (an age group with high participation in the labour market), while the currently wide cohort of prime age population will approach the upper-middle-age group, which is characterised by a steep decline in labour market participation. Until 2030, changes in the population's age structure are likely to decrease the aggregate (headline) participation rate in the Baltic countries by about 2.5-5.0 pp (Fig. 2 ), which is one of the reasons why the employment growth of about $2 \%$ per year in the absence of any increase in population (as it was recorded in the Baltic States during the recent years) is unsustainable.

Also, the decline in unemployment is likely to slow down: the lower and the more structural (rather than cyclical) unemployment is, the harder it is to achieve a further decrease. In the Baltics, unemployment rates traditionally have exceeded the EU average and most of the time since the restoration of independence in 1991 have been measured in double digits. The main reason for that is the high natural rate of unemployment (more precisely, that of the structural unemployment) due to which unemployment remained relatively high also during the expansion phase of the economic cycle (Ebeke 
Figure 1. Decomposition of the employed-to-population ratio's deviation from the EU average, $p p$, contributions, in 2018

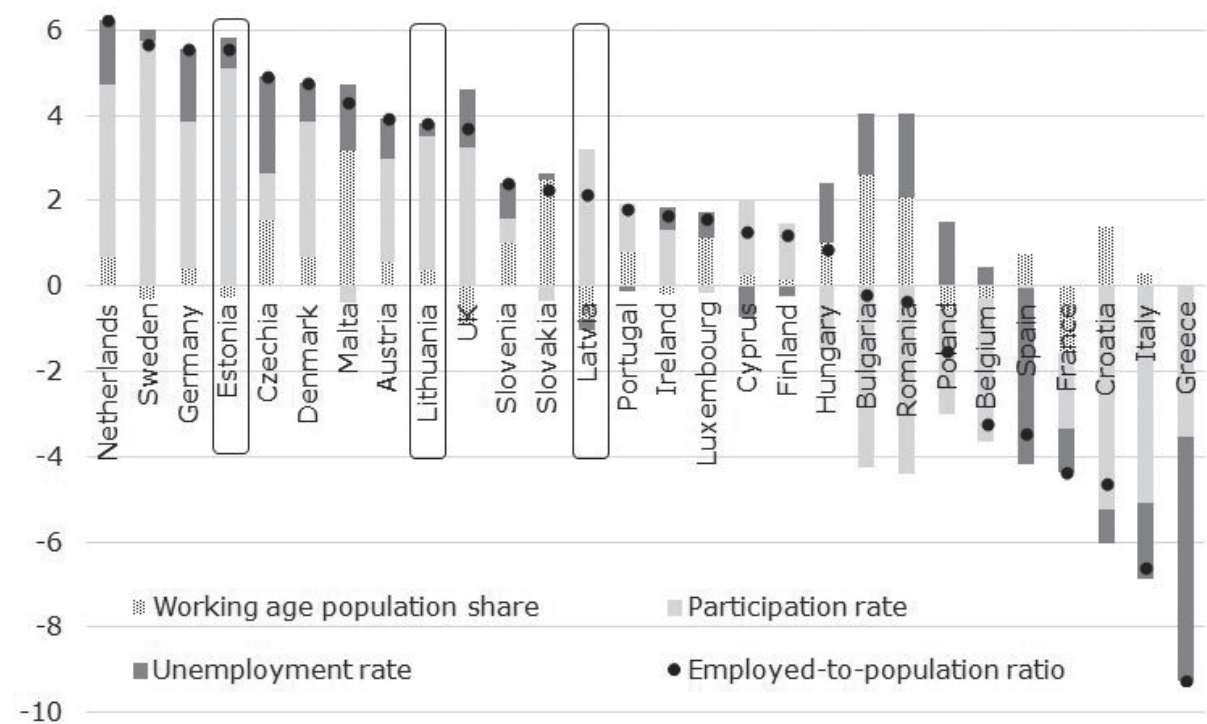

Source: Author's calculations based on Eurostat data

Figure 2. The impact of changes in the population's age structure on the headline participation rate, $p p$, compared to the age structure in 2002

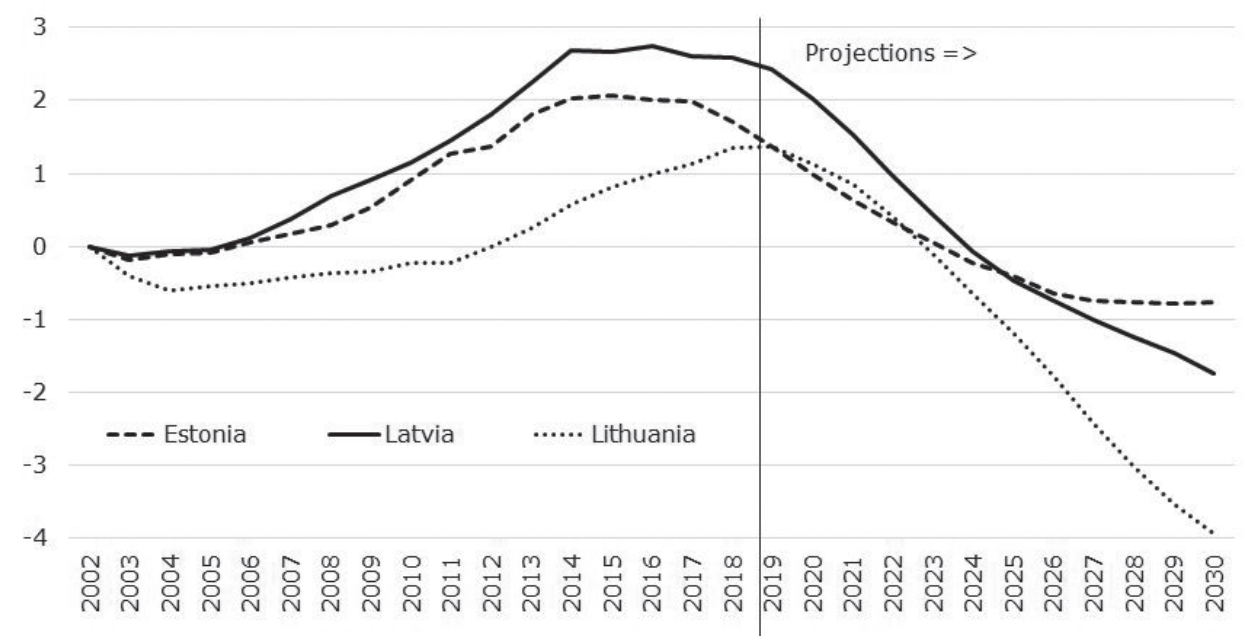

Source: Author's calculations based on Eurostat population projections data 
Figure 3. Unemployment decomposition into natural and cyclical components, $p p$, contributions, in 2018

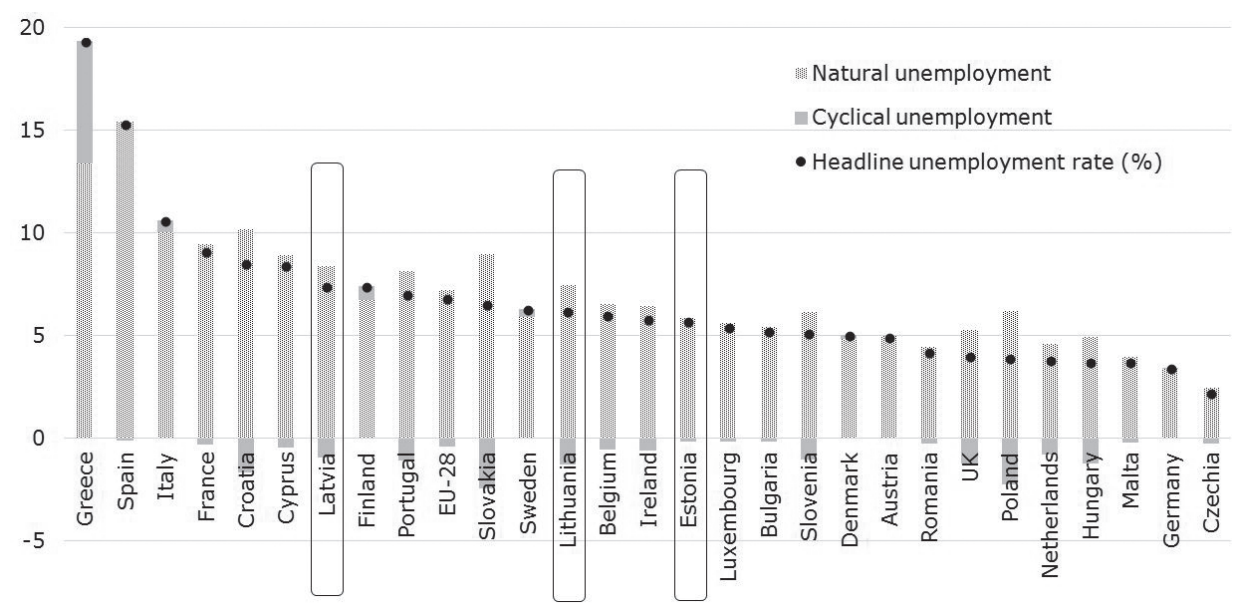

Source: Author's calculations based on AMECO data

\& Everaert, 2014; Camarero et al., 2005). Direct job creation and aggregate demand stimulus that would be a standard recipe to remedy cyclical unemployment are not relevant anymore. Following a period of marked growth during the economic slowdown of 2009-2010, cyclical unemployment is no longer evident in the Baltics since about 2013.

Although the natural rate of unemployment has decreased in the Baltics since the 1990s, the current level of 6-8\% of the workforce still looks modest by EU standards: $20 \mathrm{EU}$ countries had achieved lower natural rates of unemployment than Latvia by 2018, of which 11 countries also had lower natural rates of unemployment than Estonia (Fig. 3). This implies that high structural unemployment remains a challenge for the Baltic countries (particularly for Latvia) and potentially a significant source of internal labour reserves.

The position of the Phillips and Beveridge curves, as well as unemployment duration analysis supports the evidence that the natural rate of unemployment in Latvia tends to be somewhat higher compared to Estonia and Lithuania. The Philips and Beveridge curves for Latvia are placed somewhat higher (closer to the north-east quadrant) than those of the two other Baltic countries, mirroring higher unemployment for given wage growth or a vacancy rate. Also, the share of long-term unemployed is relatively higher in Latvia. 
Internal labour reserves do not necessarily exist only in the form of unemployment. Some jobless people fall outside a jobseekers' definition of "is available to start work within the next two weeks and has actively sought employment at some time during the last four weeks". Moreover, some parttime workers wish but are unable to find a full-time job.

The number of discouraged workers who are not looking for a job because they do not believe in finding one (although decreasing) is considerably higher in the Baltics if compared with many other EU countries. Also, the total amount of people who report that they are available for work but do not seek it in Estonia and Latvia is well above the EU average. This suggests that labour reserves in the form of hidden unemployment are mainly locked in economic inactivity where many people who are available for work, do not seek it (either because they do not believe in finding work or for other reasons).

Given the significant regional differences in employment patterns across various EU countries, to quantify labour reserves in the Baltics, it would be more relevant to compare its labour market indicators only with those of the EU countries that could be defined as peers in terms of labour market performance. Seven EU countries were selected as such peers: Germany, Austria, Denmark, the Netherlands, Sweden, the Czech Republic and the UK (hereinafter referred to as EU7). All these countries have relatively high aggregate employment and participation rates which are currently broadly at par with the Baltic countries. And neither of these countries currently has substantial output or unemployment gaps (either positive or negative), suggesting that their labour market performance mainly reflects fundamentals (like the efficiency of matching between the unemployed and vacancies) rather than a transitory impact of the economic cycle.

The employment rate of 15-19-year-olds in Latvia and Lithuania is 25 pp lower (in Estonia, 20 pp lower) than in the EU7, mainly reflecting their very low participation in the labour market. There is international evidence that young people tend to suffer more from cyclical slowdowns (Bell \& Blanchflower, 2011). In the Baltics, however, young people show consistently low employment irrespective of the cyclical economic conditions. Therefore, it most probably reflects fundamental reasons such as low incidence of professional education and prevalence of apprenticeships, or strict regulations hampering youth employment.

The relatively low employment of youth in Latvia and Lithuania is evident also in the age group 20-24, particularly for women. In comparison with 
the EU7, the employment rates of women in the age of 20-24 in Latvia and Lithuania are, respectively, $8 \mathrm{pp}$ and $11 \mathrm{pp}$ lower. In both countries, the low employment of young women mainly reflects poor participation in the labour market, while unemployment is only marginally higher than in the EU7. Few women have own children at this age. The relatively low employment most likely reflects postponed entry into the labour market.

The employment rate is also consistently low for upper-middle-aged men, with the contribution of low participation to low employment gradually increasing with age. In particular, low employment is evident for uppermiddle-aged men without a tertiary education degree. For instance, in Latvia, the employment rate of men in the age group $45-59$ is by $15-25$ pp lower than the respective rate in the EU7 if having basic education and 10-15 pp lower if having secondary education. Figures for Lithuania are broadly similar, while the underemployment of upper-middle-aged men in Estonia is less pronounced.

By raising the employment rate to the level of the EU7 in population groups which were consistently underemployed compared to the EU7, Estonia, Latvia and Lithuania could increase employment by more than 25,000, 55,000 and 85,000 people, respectively, which corresponds to $4-7 \%$ of total employment in these countries (Table 1).

Managing to increase the employment rates in each population group up to the current levels of the EU7 does not necessarily mean that the internal labour reserves in the Baltic countries would be fully exhausted. The movement towards the EU7 employment rates is similar to the income convergence concept in a sense that the target is a dynamic one, rather than static. Employment rates in the EU7 countries tend to increase over time. For instance, currently, nearly two-thirds of 60-64-year-old men are employed in the EU7 countries, compared to approximately one third at the beginning of the century. The EU7 employment rates tend to increase in several other age groups, too. Consequently, the lagging behind the EU7 in terms of the employment rates in some population groups indicates the current amount of labour reserves; in the future, additional labour reserves might be discovered, for instance, due to a global improvement in the work skills and health condition of seniors. 
Table 1. Internal labour reserves in the Baltic countries by age group and gender, thousands of people, in 2018.

\begin{tabular}{|c|c|c|c|c|c|c|c|}
\hline & \multicolumn{2}{|c|}{ Estonia } & \multicolumn{2}{|c|}{ Latvia } & \multicolumn{2}{|c|}{ Lithuania } \\
\hline & & Men & Women & Men & Women & Men & Women \\
\hline \multirow{11}{*}{$\begin{array}{l}\text { 을 } \\
\text { 인 } \\
\text { ㅁ } \\
\text { ㅁ⿺ㄴ }\end{array}$} & $15-19$ & 6.3 & 5.0 & 11.3 & 11.1 & 17.1 & 17.8 \\
\hline & $20-24$ & & & 0.6 & 3.4 & 8.1 & 9.1 \\
\hline & $25-29$ & & 2.4 & 1.9 & 0.1 & & \\
\hline & $30-34$ & & 2.6 & 1.8 & & 1.1 & \\
\hline & $35-39$ & & 1.2 & 1.2 & 1.7 & 2.1 & \\
\hline & $40-44$ & & 0.5 & 2.3 & & 7.6 & \\
\hline & $45-49$ & 1.5 & & 5.5 & & 9.0 & \\
\hline & $50-54$ & 1.3 & & 6.0 & & 7.0 & \\
\hline & $55-59$ & 4.4 & & 5.2 & & 7.4 & \\
\hline & $60-64$ & 1.7 & & 3.8 & & & \\
\hline & Total & & 6.9 & & .9 & & .3 \\
\hline
\end{tabular}

Source: Author's calculations based on Eurostat data

Notes: Labour reserves are defined only for those population groups where the employment rate is below the EU7. Labour reserves reflect additional employment that would be observed if the employment rates reached the level of the EU7.

\section{Policy directions to activate labour reserves}

This chapter discusses four broad policy directions which might contribute to the activation of internal labour reserves: education, healthcare, labour market regulations as well as a particular focus on people living in regions with low economic activity and ethnic minorities.

\subsection{Education and skills}

Academic literature often ties low men employment with ever-decreasing labour demand for unskilled men (Binder \& Bound, 2019). Although all three Baltic countries are characterised by decent quantitative indicators of education, the quality of education varies. In Estonia, the education quality indicators are better than in Latvia and Lithuania, yet some of them still lag behind the EU7. In addition, Estonia has a larger incidence of lifelong learning and better digital skills of the adult population, which are likely 
contributors to maintaining a lower natural rate of unemployment and smaller underemployment of upper-middle-aged men.

Estonian students consistently achieve one of the highest Programme for International Student Assessment (PISA) scores among the EU countries, while their counterparts in Latvia and Lithuania show only modest results; and this difference is obvious in all three PISA subjects: science, reading and mathematics. All three Baltic countries are among the EU leaders in terms of education spending as a share of the general government budget. Yet the school system is the most consolidated in Estonia where the number of teachers and schools relative to the number of students is the lowest in the Baltics, and the teachers' wages are consequently significantly higher. Latvia, on the contrary, maintains a wide network of small schools which are unable to afford neither adequate wages for their teachers nor good education standards for their students. School size and teachers' wages are the two variables most closely associated with the educational performance of school students in Latvia (Krasnopjorovs, 2019b).

Global Competitiveness Report (GCR) data confirm that science and math education in Estonia consistently outperforms both other Baltic countries and the EU7. Teaching in Estonia also encourages more creative and critical individual thinking and is less focused on memorising than in Latvia and Lithuania, which is broadly at par with the EU7. Although the quality of management schools in Estonia also tends to be higher than in the other Baltic countries, it still lags behind the EU7. These results are further supported by university ranking platforms. For instance, according to the QS World University Rankings, several Estonian universities are placed considerably higher than their counterparts in Latvia and Lithuania, but still behind some regional universities in the Scandinavian countries, such as Finland. As a result, employers regard Estonian graduates as possessing skills that are more in line with the labour market needs in comparison with those of the graduates in Latvia and Lithuania (GCR data).

Moreover, Estonia still outperforms both other Baltic countries in terms of digital skills and lifelong learning (Fig. 4). For instance, only 3\% of men aged 45-54 years in Latvia and Lithuania reported participating in education or training programmes during the last four weeks, while in Estonia and the EU7 the respective figure was about $12 \%$. Not surprisingly, underemployment of upper-middle-aged men in Lithuania and Latvia is considerably higher than in Estonia. 
Figure 4. The Baltic countries vs EU7: digital skills and lifelong learning, difference, $p p$

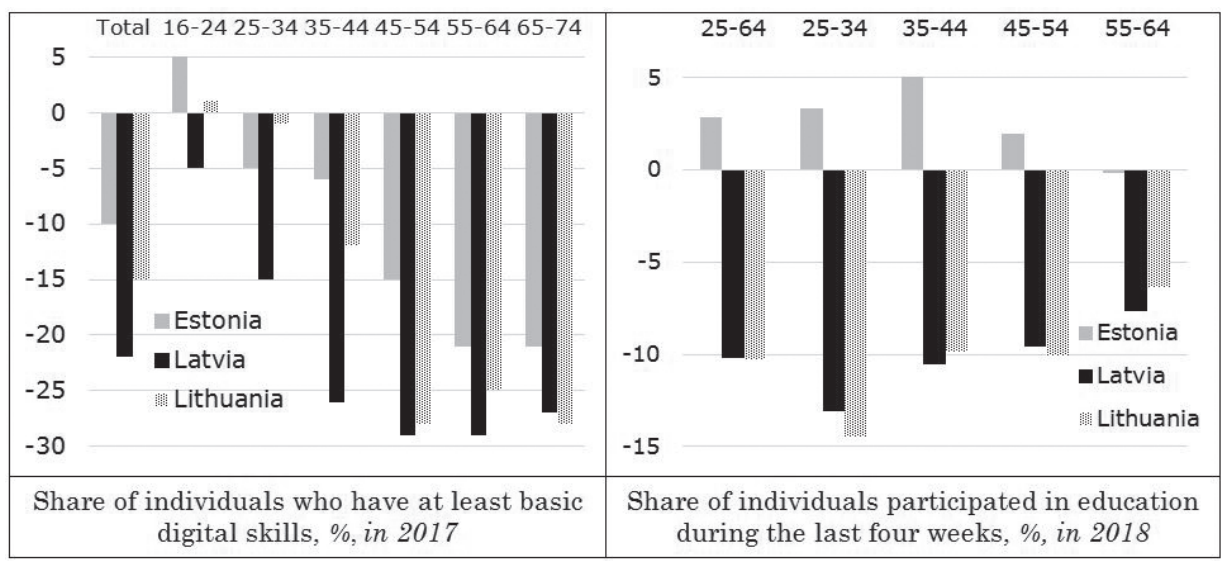

Source: Author's calculations based on Eurostat data

\subsection{Health}

Another factor most likely to impede the employment of upper-middle-aged men in the Baltic countries is their rapidly deteriorating health condition. For instance, healthy life expectancy for 50-year-old men in the Baltic countries, although gradually increasing, is only 11-14 years, which is still one of the lowest in the EU and substantially lags behind the EU7. The selfassessed health status of the upper-middle-aged men is also relatively low in the Baltics by EU standards with a large share of people assessing their health as bad or very bad, particularly in Latvia and Lithuania (Fig. 5).

The health condition depends on a wide variety of factors, and some of them are outside the direct control of policymakers. Among observable indicators, the Baltic countries not only have one of the lowest healthcare spendings in the EU but also relatively low efficiency of the healthcare system. Latvia and Lithuania, in particular, have managed to maintain a relatively large number of hospital beds, doctors and medical equipment (for instance, magnetic resonance units) at low costs, mainly reflecting low wages in the healthcare sector. However, decent levels of these intermediate outputs did not easily translate into the outcomes such as healthy life expectancy, reflecting the low efficiency of the healthcare system (Medeiros \& Schwierz, 2015). The large share of private out-of-pocket spending further decreases the accessibility of healthcare services, particularly by low-income households. In addition, the population's health condition in the Baltic countries is likely 
Figure 5. Life expectancy and self-perceived health-status of uppermiddle-aged men

\begin{tabular}{|c|c|}
\hline $\begin{array}{c}15 \\
10 \\
5 \\
0\end{array}$ & $\begin{array}{r}100 \\
90 \\
80 \\
70 \\
60 \\
50 \\
40 \\
30 \\
20 \\
10 \\
0 \\
0\end{array}$ \\
\hline Life expectancy of 50 years old men, years, in 2016 & Self-perceived health status, index; age 55-64; in 2017 \\
\hline
\end{tabular}

Source: Author's calculations based on Eurostat data

to be impeded by unhealthy lifestyles, particularly by the relatively high consumption of tobacco and alcohol as well as low physical activity.

In fact, the differences in the health condition of the Baltic and EU7 population actually emerge much earlier than at the upper-middle age. Adolescents in the Baltics are already significantly less healthy than their peers in the EU7. Given a strong link between health status in young age and subsequent employment prospects established in academic literature (Case et al., 2005), this suggests that without a substantial improvement in health quality standards, underemployment of upper-middle-aged men (and the resulting loss of GDP and well-being) is likely to persist.

\subsection{Labour market regulation}

Strict labour market regulation tends to be associated with downward wage rigidity (Babecky et al., 2010), which can hamper employment level. Thus, several EU countries have implemented complex structural reforms to liberalise their labour markets (Masuch et al., 2018). This article looks at several dimensions of labour market regulation in the Baltic countrieslabour market flexibility, taxation of labour income and the minimum wage in order to see by which extent these might contribute to the relatively low employment compared to EU7. 
Labour market de facto flexibility in the Baltic countries is a well-known fact. For instance, in Latvia, firms found it relatively easy to decrease wages and dismiss permanent employees during the recent economic crisis (Fadejeva $\&$ Krasnopjorovs, 2015). The trade union density and collective bargaining coverage remain very low in the Baltics, with wages being set mainly at an individual level. GCR also traditionally places all three Baltic countries among the economies with the most flexible wages.

However, there is a marked difference between labour market elasticity de facto and de jure. In particular, Latvian legislation in the area of employment relationships is one of the strictest in the OECD. For instance, according to the law, the protection of permanent workers in Latvia is as strict as in Belgium and Italy. Nevertheless, several rules that formally could be evaluated as strict either cannot be enforced or can be easily evaded (Eamets, 2013).

The difference between the tight regulation de jure and the labour market flexibility de facto is also related to the large share of shadow economy as well as heavy, long and expensive legal procedures, which can motivate employees to decide to quit the job "voluntarily" without exercising the strict labour market regulation for their own benefit. However, even if not executed, strict labour market regulations might distort the labour market. Strict regulations may deter investors, particularly if they do not know that a considerable part of OECD employment protection index components is regulated only on paper. Moreover, labour shortage can complicate law evasion, thus increasing labour market distortion.

The bigger the difference between labour costs and net wages, the larger structural unemployment and the shadow economy. Although the tax rates on labour income in Latvia and Lithuania are somewhat lower than in the EU7, the GCR survey data reveal that labour taxation tends to reduce work incentives to a greater extent than in the EU7. Perhaps the public perception of the efficiency of government expenditure is one of the indicators determining the extent to which a given tax wedge is perceived as distortive. Estonia has somewhat lower labour tax rates and significantly higher perception of the efficiency of government expenditure (at least as revealed by the GCR data). Consequently, labour taxes in Estonia are assessed to be less distortive to work incentives than those in Latvia and Lithuania. This aligns well with the observation that Estonia, over the years, has had a higher employment rate and a lower natural rate of unemployment than the other Baltic countries. 
The minimum wage is another important labour market regulation indicator. Employers tend to react to minimum wage increases, inter alia, by dismissing employees, postponing recruitment of new employees and raising prices (Neumark \& Wascher, 2008). Thus, too high minimum wages could increase the natural rate of unemployment, hidden unemployment or the spread of the shadow economy.

In the Baltics, the current minimum-to-average wage ratio (somewhat above $40 \%$; see Fig. 6) is broadly at par with the EU average. However, minimum wages could still distort the labour market in the sectors and regions with the lowest wages. For instance, in Latgale (eastern Latvia) the minimum-to-average wage ratio exceeds $60 \%$, which is a very high number by international standards. Also historically, Latgale has had a very high unemployment rate. Therefore, when considering further minimum wage rises, account should be taken not only of its ratio to the average wage but also of the whole wage distribution to ensure that minimum wages do not distort the labour market segment of low-wage earners.

Figure 6. Minimum-to-average wage ratio, $\%$

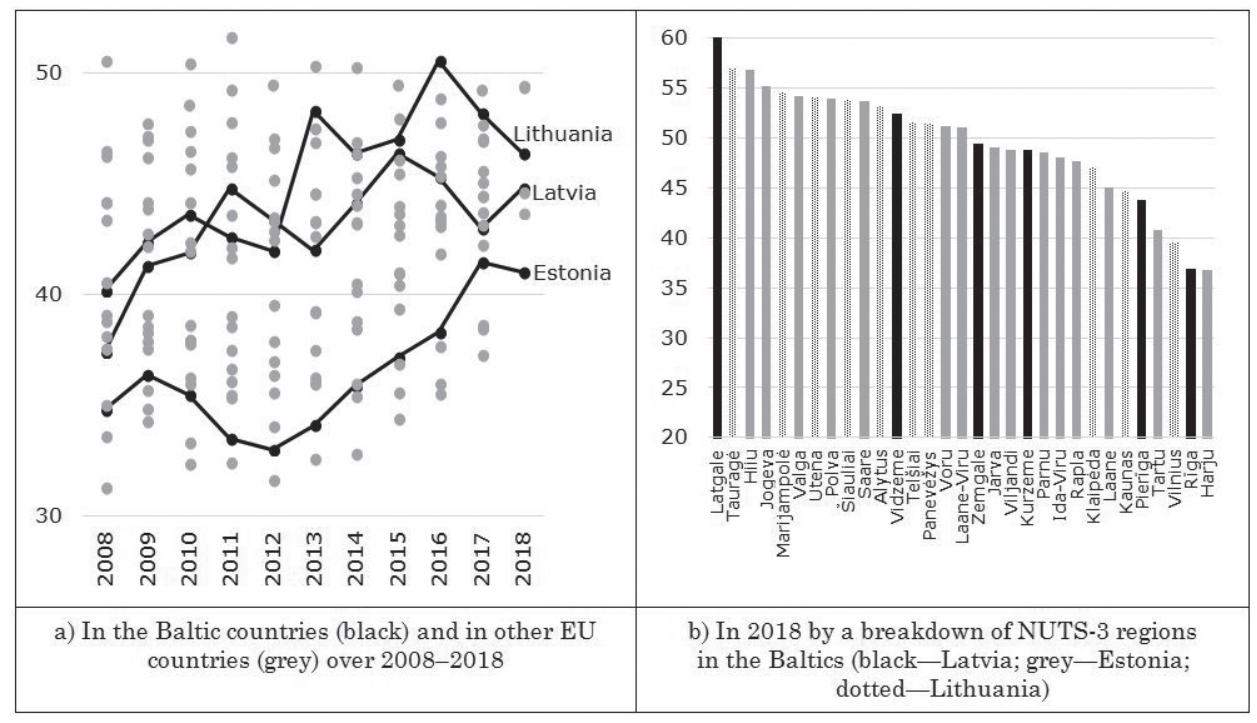

Source: Author's calculations based on data from the CSB, Statistics Estonia, Statistics Lithuania and Eurostat 


\subsection{Targeting particular regions and population groups}

Many countries have large regional disparities in terms of labour market performance (Robson, 2009), and the Baltic countries are no exception. The employment rate difference between the NUTS-3 regions with the highest and the lowest employment rate within a country was $12-17 \mathrm{pp}$ in 2018. For instance, while the employment rate in the Latvian capital city Riga is similar to the record-high levels observed in Sweden and Germany, it is close to the level of Spain in the eastern part of Latvia (Latgale).

Weak labour market performance of some Baltic regions cannot be explained by a single factor (for instance, a low level of human capital). On the one hand, there is insufficient evidence that the education of Latgale inhabitants differs much from that of the rest of Latvia's population in terms of quantity or quality. On the other hand, the multiplicative effects of regions and education on unemployment are apparent. The demand for employees with a tertiary education degree is similar in all regions of Latvia; unemployment is below 5\% everywhere, including Latgale. In turn, the unemployment rate among people with basic education differs substantially between regions, i.e., in Latgale it is close to $30 \%$, which is three times higher than in the suburbs of Riga (Pieriga). Therefore, people with a low level of education are most affected by regional unemployment differences. Two possible remedies are either retraining of Latgale inhabitants having an inadequate education level or promotion of their mobility to other regions of Latvia. In turn, the creation of very-low-paid temporary public sector jobs in disadvantaged regions (which is a common practice in Latvia) tends to freeze the current labour market conditions.

The high unemployment rates in Latgale (Latvia) and Ida-Viru (Estonia) cannot be fully explained by the fact that a large share of inhabitants living in these regions are ethnic minorities. For instance, unemployment in Latgale is higher (and the participation rate lower) also among the ethnic majority. The fact that a lower employment rate of ethnic minorities is very common internationally (see, e.g., Gorinas, 2014) does not mean that this should always remain the case. Therefore, a low employment rate of ethnic minorities points to potential labour reserves. Currently, the employment rate of ethnic majorities in Latvia and Estonia is higher than among ethnic minorities, and the difference remains broadly unchanged over the post-crisis period.

In Latvia, the difference in the employment rate between the ethnic majority and ethnic minorities is more prominent than in Estonia ( 8 and 
$5 \mathrm{pp}$, respectively). Latvians have been employed more often than nonLatvians over the entire post-crisis period, reflecting both higher labour market participation of Latvians and lower unemployment. Note, however, that the employment rate among Latvians and non-Latvians was rather similar during the short period of economic overheating just before the crisis. The emergence of an ethnic gap in the employment rate may reflect the different exposure of economic sectors to the crisis; namely, the construction and private sector in general, where over-proportional employment of nonLatvians prevailed, experienced more sizeable layoffs during the crisis, while dismissals were less common in the public sector characterised by a disproportionate employment of Latvians. A similar employment rate between the ethnic majority and ethnic minorities during the pre-crisis period was also observed in Estonia.

Although the ethnic gap in the employment rate is particularly wide for the upper-middle-aged population, it is evident for younger cohorts as well. This suggests that, at least partly, the ethnic gap in the employment rate is likely to persist (rather than vanish on account of generation renewal) without a special policy targeted at ethnic minorities, and the respective labour reserves might not be fully accessed.

\section{The impact of the Covid-19 pandemic on the Baltic labour markets}

The Covid-19 outbreak and its containment measures substantially decrease economic activity, which inevitably translates into higher unemployment, and thus, increases the available labour reserves. However, there still exists large uncertainty regarding both the magnitude of economic slowdown and the shape of subsequent recovery.

There is a broad consensus among international organisations that the unemployment rate in the Baltic countries during 2020-2021 could exceed that in 2018. Particularly, in Latvia and Lithuania, the unemployment rate is likely to surpass the $10 \%$ threshold for a while (Fig. 7). In all three countries, however, unemployment is expected to remain lower than during the global financial crisis. Flash unemployment data show that the intensity of layoffs during March and April 2020 was compared to that during 2009. However, the impact of Covid-19 crisis on the labour market is likely to be relatively shorter and significantly mitigated by the countercyclical expansionary 
policies. Both anecdotal evidence and unemployment data suggest that the intensity of layoffs eased substantially as of June 2020 .

Figure 7. Unemployment forecast for 2020-2021 in the Baltic countries, \% of the economically active population

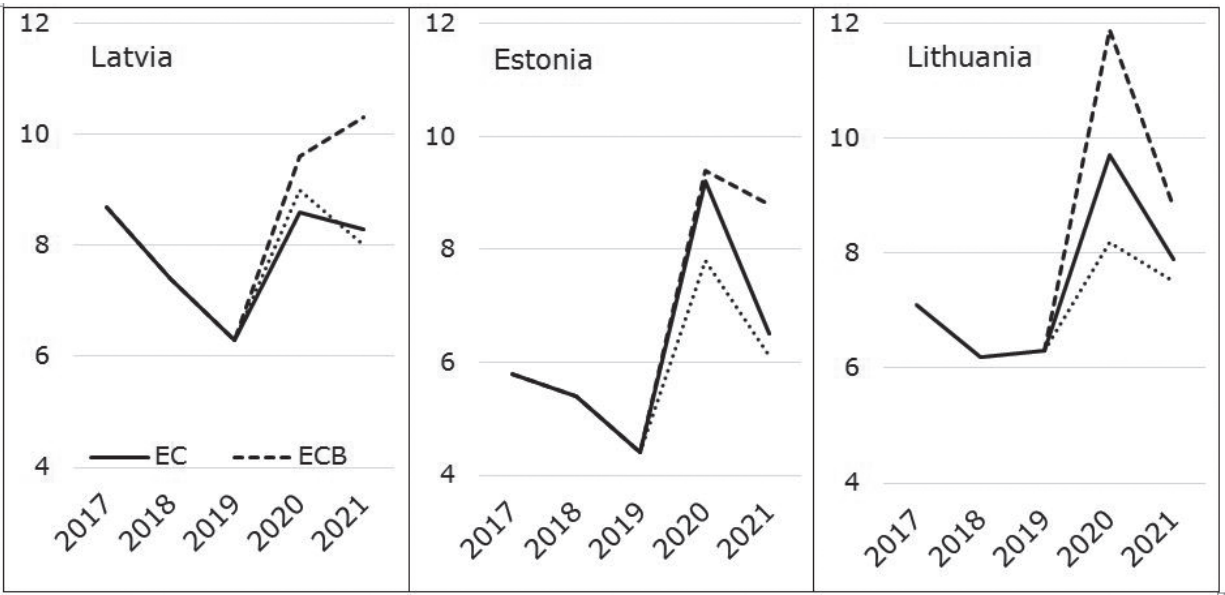

Source: EC, ECB and IMF data

Notes: The Graph shows unemployment forecast of the European Commission (May 2020, EC), the European Central Bank (June 2020, ECB) and the International Monetary Fund (October 2020, IMF)

The Baltic countries were less affected by the Covid-19 outbreak than the EU on average-both the total number of Covid-19 cases and the number of related deaths was smaller than in several other EU countries. Also, the Covid-19 restrictive measures have been relatively mild, and, thus, the negative impact on economic activity is likely to be smaller. For instance, Google Mobility Report shows that the number of visits to workplaces and transit stations during spring and summer 2020 decreased less than in many other EU countries (except for Lithuania, it is true also for retail and recreation centres). Similarly, time spent at home in the Baltic countries has converged to the values observed during the reference period (Fig. 8). Thus, the increase in unemployment related to Covid-19 in the Baltic countries might be smaller than in the EU on average.

Regarding the impact of the Covid-19 outbreak on the structure of labour reserves, there are both similarities and notable differences with the impact of the 2008-2009 global financial crisis. For instance, the global financial crisis particularly hit construction and manufacturing-the sectors in which the vast majority of employees are men; consequently, unemployment 
rate for men increased much faster than for women. In turn, the Covid-19 pandemic has a bigger impact on services, where women predominate (Fana et al., 2020). Thus, the share of women in the available labour reserves might increase.

Figure 8. Population mobility indicators, \%, compared to 3 January - 6 February 2020, centered 7-day moving average

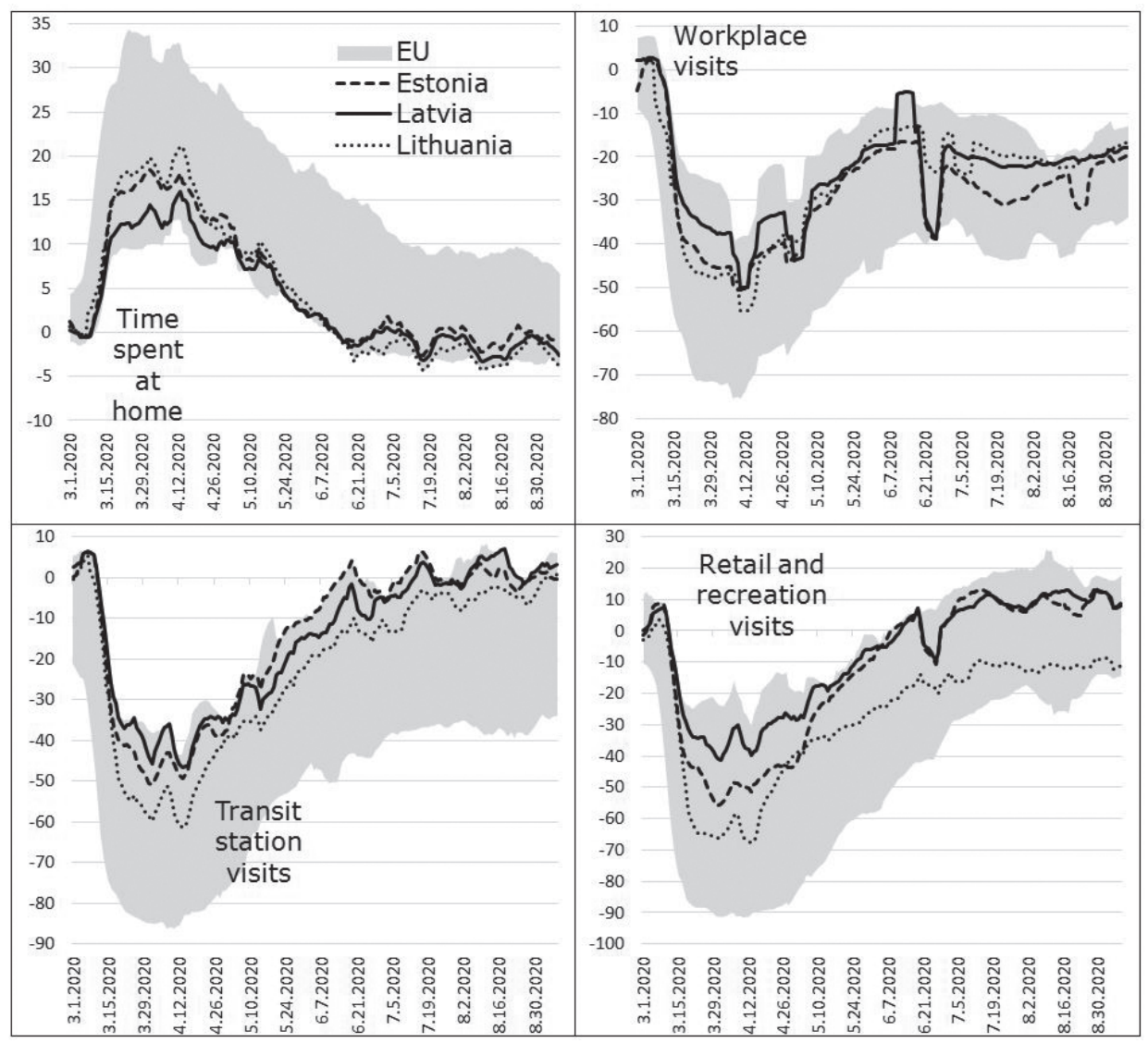

Source: Google COVID-19 Community Mobility Reports, author's calculations

Notes: Transit stations are places like public transport hubs such as subway, bus, and train stations. Retail and recreation are places like restaurants, cafes, shopping centres, theme parks, museums, libraries and movie theatres.

Moreover, different regions and municipalities showed uneven unemployment dynamics during the Covid-19 pandemic. In spring 2020, the biggest rise in unemployment was recorded in big cities, which might reflect both the larger share of services in the value added and the bigger 
impact of Covid-19 containment measures on densely populated areas. For instance, among 119 Latvian municipalities, particularly Riga and the municipalities located around the capital city recorded the steepest rise in the unemployment rate between February and May 2020. Since big cities initially had lower unemployment than rural areas, it may turn out that Covid-19 might decrease labour shortage in the municipalities where it was the most pronounced.

As for the structure of labour reserves in terms of education level and age groups, the impact of Covid-19 seems to be similar to the impact of the global financial crisis. Namely, the rise in unemployment tends to be the steepest for vulnerable population groups-people with a low education level and youth (Fana et al., 2020). Employees with low education and skills are less likely to be hoarded during economic slowdowns (Bryson \& Forth, 2015). Moreover, the Covid-19 pandemic disproportionately affected hotels and restaurants - the sector in which young people traditionally constitute a relatively big share of employment.

\section{Research limitations}

Several research limitations should be mentioned. First, the scope of the paper is limited mainly to the supply side of the labour market. This limitation is justified with a consideration that none of the Baltic countries had a significant output gap (and, thus, cyclical unemployment) over the last few years preceding the Covid-19 outbreak. For the extent to which output gap estimates may suffer from imprecision, our estimate of labour reserves might be biased. Therefore, the results of Section 1 (particularly Table 1) should be viewed as a rough estimate of the magnitude and structure of available labour reserves, rather than a precise number of people that could be activated.

Second, an empirical investigation of the impact of particular public policy measures on employment is certainly beyond the scope of this paper. Thus, based on academic literature for the other countries, this paper discusses rather broad fields like 'education' and 'healthcare' as public policy tools to activate labour reserves. The employment of upper-middle-age men in the Baltic countries is substantially lower than in the EU7, and this observation is linked to a gap in skills and health (between the Baltics and the EU7) which is particularly wide for this population group. This coincidence, at 
least, is worth mentioning. In turn, considerations like the extent to which major underemployment exists due to inadequate skills, and, even further, which skills exactly should be upgraded to activate labour reserves in each particular population group, are left for further research. It might appear that for many people it will not be possible to identify a single reason of nonemployment, rather this might happen due to a combination of factors (e.g., simultaneously possessing poor health, inadequate digital skills and being an ethnic minority).

Besides, it might be questioned why ethnic minorities are considered as a separate category if there is no evidence that they possess significantly different levels of either skill or health adequacy. It is at least worth mentioning that ethnic minorities in the Baltic countries have considerably lower employment rates and higher unemployment rates. Therefore, the share of ethnic minorities in labour reserve exceeds the share of ethnic minorities in the working-age population. Without targeting at least some of the public policies to ethnic minorities, the Baltic countries will not be able to activate their labour reserves fully.

\section{Conclusions}

This paper investigates the internal labour reserves in Latvia, Estonia and Lithuania, the three Baltic countries that have experienced a chronic shortage of jobs for years, but more recently, as a result of recent robust economic growth and ongoing emigration to wealthier EU countries, were facing an ever-increasing labour shortage. Although cyclical unemployment is currently almost non-existent and natural unemployment has decreased somewhat during the last 15 years, the natural rate of unemployment of about $6-8 \%$ is still well above the best-performing EU countries. This corresponds well with the earlier findings of Ebeke \& Everaert (2014) and Camarero et al. (2005). We also find considerable internal labour reserves in the form of hidden unemployment as many economically inactive people are available for work but not actively engaged in jobseeking.

International comparisons with the EU best-performing countries reveal that the employment rate is particularly low among upper-middle-aged men. The employment rate of men aged 45-59 is almost $10 \mathrm{pp}$ lower in Latvia and Lithuania than in their EU peers. In line with the international evidence (Binder \& Bound, 2019), underemployment is particularly severe 
among the upper-middle-aged men without a tertiary education degree. Their employment rate is one of the lowest in the EU, which is likely to reflect a low incidence of lifelong learning, insufficient digital skills and a rapidly deteriorating health condition.

We also document low youth employment, mirroring a low prevalence of apprenticeships. In addition to suffering more from cyclical slowdowns (Bell \& Blanchflower), young people (aged 15-19) in the Baltic countries consistently show 20-25 pp lower employment rate than their EU peers; and this gap is broadly similar among young men and women. Lithuania and Latvia are also characterised by a postponed entry of young women (aged 20-24) into the labour market.

The estimates given here suggest that internal labour reserves currently exceed 25,000 people in Estonia, 55,000 in Latvia and 85,000 in Lithuania. This corresponds to $4-7 \%$ of the total employment in these countries. A particular targeting of ethnic minorities and people living in disadvantaged regions is essential for activating the internal labour reserves as labour market performance differs substantially by region and is considerably worse for ethnic minorities. The recent outbreak of the Covid-19 pandemic is likely to increase the available labour reserves and change its structure. People with low education and youth are particularly vulnerable to layoffs during economic slowdowns. Moreover, due to different exposure by regions and economic sectors, the Covid-19 crisis may particularly increase the unemployment rate in big cities and for women.

So far, the impact of the shrinking population and the share of the workingage population has been offset by a rapid increase in the participation rate and falling unemployment. However, the upturn in the participation rate over the last two decades was partly driven by a changing population age structurean effect which is likely to reverse in the following years. Therefore, without deeper activation of the internal labour reserves, the number of people employed is going to shrink in Latvia and Lithuania in the nearest future.

Olegs Krasnopjorovs has worked at the Bank of Latvia since 2006 and is currently chief economist of the Monetary Policy Department. His research interests cover the topics of labour market, inflation forecasting and economic development. Olegs holds a doctoral degree in economics (subfield of econometrics) from the University of Latvia. 


\section{References}

Åslund, A. \& Dombrovskis, V. (2011), How Latvia Came through the Financial Crisis, Washington, DC: Peterson Institute for International Economics Press. Retrieved from https://www.piie.com/bookstore/how-latvia-came-throughfinancial-crisis [accessed Oct 2020]

Babecky, J.; Du Caju, P.; Kosma, T., Lawless, M.; Messina, J. \& Room, T. (2010), 'Downward nominal and real wage rigidity: survey evidence from European firms,' Scandinavian Journal of Economics, vol. 112, no. 4, pp. 884-910. https://doi.org/10.1111/j.1467-9442.2010.01624.x

Bell, D. N. F. \& Blanchflower, D. G. (2011), 'Young people and the Great Recession,' Oxford Review of Economic Policy, vol. 27, no. 2, pp. 241-267. https://doi.org/10.1093/oxrep/grr011

Binder, A. J. \& Bound, J. (2019), 'The declining labor market prospects of lesseducated men,' Journal of Economic Perspectives, vol. 33, no. 2, pp. 163-190. https://doi.org/10.1257/jep.33.2.163

Blanchflower, D. G. \& Levin, A. T. (2015), Labor Market Slack and Monetary Policy, National Bureau of Economic Research Working Paper, no. 21094. https://doi.org/10.3386/w21094

Bryson, A. \& Forth, J. (2015), The UK’s Productivity Puzzle, IZA Discussion Paper, no. 9097, Institute of Labor Economics (IZA).

Camarero, M.; Carrion-i-Silvestre, J. L. \& Tamarit, C. (2005), 'Unemployment dynamics and NAIRU estimates for accession countries: a univariate approach,' Journal of Comparative Economics, vol. 33, no. 3, pp. 584-603.

https://doi.org/10.1016/j.jce.2005.04.001

Case, A.; Fertig, A. \& Paxson, C. (2005), 'The lasting impact of childhood health and circumstance,' Journal of Health Economics, vol. 24, no. 2, pp. 365-389. https://doi.org/10.1016/j.jhealeco.2004.09.008

Eamets, R. (2013), 'Labour market and labour market policies during Great Recession: the case of Estonia,' IZA Journal of European Labor Studies, vol. 2, no. 4, pp. 1-25. https://doi.org/10.1186/2193-9012-2-4

Ebeke, C. H. \& Everaert, G. (2014), Unemployment and Structural Unemployment in the Baltics, International Monetary Fund Working Paper, no. 14/153. Retrieved from https://www.imf.org/en/Publications/WP/Issues/2016/12/31/ Unemployment-and-Structural-Unemployment-in-the-Baltics-41849 [accessed Oct 2020]

Fadejeva, L. \& Krasnopjorovs, O. (2015), Labour Market Adjustment during 2008-2013 in Latvia: Firm Level Evidence, Latvijas Banka Working Paper, no. 2/2015. Retrieved from https://www.makroekonomika.lv/sites/default/files/ wp_2-2015_en.pdf [accessed Oct 2020] 
Fana, M.; Tolan, S.; Torrejón, S.; Urzi Brancati C. \& Fernández-Macías, E. (2020), The COVID Confinement Measures and EU Labour Markets, European Commission, JRC Technical Reports. https://doi.org/10.2760/079230

Gorinas, C. (2014), 'Ethnic identity, majority norms, and the native-immigrant employment gap,' Journal of Population Economics, vol. 27, pp. 225-250. https://doi.org/10.1007/s00148-012-0463-3

Green, A. E. \& Hasluck, C. (1998), '(Non)Participation in the labour market: alternative indicators and estimates of labour reserve in United Kingdom Regions,' Environment and Planning, vol. 30, no. 3, pp. 543-558. https://doi. org/10.1068/a300543

Krasnopjorovs, O. (2019a), Anatomy of Labour Reserves in the Baltic Countries: A Snapshot 15 Years after the EU Accession, Latvijas Banka Discussion Paper, no. 2. Retrieved from https://datnes.latvijasbanka.lv/papers/discussion/ dp_2_2019-en.pdf [accessed Oct 2020]

Krasnopjorovs, O. (2019b), 'Why is education performance so different across Latvian schools?' Economic Transition and Institutional Change, vol. 27, no. 4, pp. 971-987. https://doi.org/10.1111/ecot.12227

Masuch, K.; Anderton, R.; Setzer, R. \& Benalal, N. (2018), Structural Policies in the Euro Area, European Central Bank Occasional Paper, no. 210. Retrieved from https://www.ecb.europa.eu/pub/pdf/scpops/ecb.op210.en.pdf [accessed Oct 2020]

Medeiros, J. \& Schwierz, C. (2015), Efficiency Estimates of Health Care Systems, European Commission Economic Paper, no. 549. Retrieved from https:// ec.europa.eu/economy_finance/publications/economic_paper/2015/pdf/ecp549_ en.pdf [accessed Oct 2020]

Neumark, D. \& Wascher, W. L. (2008), Minimum Wages, Cambridge, MA: MIT Press. https://doi.org/10.7551/mitpress/9780262141024.001.0001

Robson, M. (2009), 'Structural change, specialization and regional labour market performance: evidence for the UK,' Applied Economics, vol. 41, no. 3, pp. 275-293. https://doi.org/10.1080/00036840601007278 